\title{
Analisis Kesalahan Gramatika Dalam Makalah Mahasiswa Program Studi Pendidikan Olahraga Dan Kesehatan Pada Matakuliah Bahasa Indonesia Semester II
}

\author{
Supriadin \\ Dosen Universitas Pendidikan Mandalika Mataram \\ supriadin@ikipmataram.ac.id
}

\begin{abstract}
Abstrak: Penelitian ini bertujuan untuk (1) mengetahui bagaiamana kesalahan struktur kalimat dalam makalah mahasiswa Program Studi Pendidikan Olahraga dan Kesehatan pada mata kuliah Bahasa Indonesia semester II dan (2) mengetahui bagaimana kesalahan pembentukan kata dalam makalah mahasiswa Program Studi Pendidikan Olahraga dan Kesehatan pada mata kuliah Bahasa Indonesia semester II. Penelitian ini merupakan penelitian deskriptif kualitatif. Subjek penelitian yaitu makalah mahasiswa Program Studi Pendidikan Olahraga dan Kesehatan pada mata kuliah Bahasa Indonesia semester II, sedangkan objek penelitiannya adalah kesalahan struktur kalimat serta kesalahan pembentukan kata pada makalah mahasiswa Program Studi Pendidikan Olahraga dan Kesehatan pada matakuliah Bahasa Indonesia semester II. Data dikumpulkan melalui metode dokumentasi dan dianalisis menggunakan metode analisis data deskriptif kualitatif. Hasil penelitian ini menunjukkan bahwa (1) kesalahan struktur kalimat yang terdapat dalam makalah terjadi karena mahasiswa sering melakukan kesalahan penggunaan kata sehingga kalimat-kalimat tersebut menjadi pragmentaris, pleonastis, kontaminasi, ambigu, tidak ringkas, dan tidak padu dan (2) kesalahan pembentukan kata yang terjadi dalam makalah yang diteliti terjadi karena kesalahan penggabungan kata dasar yang berawalan $[\mathrm{k}]$, [p], [t], dan [s] dengan awalan meN-.
\end{abstract}

Kata kunci: Analisis Kesalahan, Kalimat, Pembentukan Kata

\section{PENDAHULUAN}

Sebagian masyarakat Indonesia merasa bahwa mereka telah memiliki kemampuan berbahasa Indonesia yang baik. Keadaan ini disebabkan oleh Bahasa Indonesia merupakan bahasa ibu yang telah mereka pergunakan sejak mulai mampu berbicara. Hal ini membuat masyarakat merasa tidak perlu untuk mempelajari Bahasa Indonesia secara lebih mendalam lagi. Hal inilah yang menyebabkan banyak terjadi kesalahan berbahasa dalam masyarakat.

Kesalahan berbahasa yang banyak terjadi adalah kesalahan pada tata Bahasa yang digunakan. Tarigan (1998:65) menyatakan bahwa hubungan antara pengajaran bahasa dan kesalahan berbahasa diibaratkan sebagai hubungan antara air dan ikan, seperti ikan yang hanya mampu hidup di air, begitulah kesalahan berbahasa sering terjadi dan terdapat dalam pengajaran bahasa. Hal inilah yang menyebabkan keterampilan berbahasa selalu diajarkan dalam setiap jenjang pendidikan, mulai dari pendidikan SD, SMP, SMA, bahkan hingga ke Perguruan Tinggi.
Dalam pengajaran bahasa, ada empat keterampilan berbahasa yang diajarkan yaitu menyimak, berbicara, membaca, dan menulis. Empat keterampilan tersebut memiliki hubungan yang sangat erat. Salah satu keterampilan yang penting dikuasai untuk membina tata Bahasa Indonesia adalah menulis. Menulis merupakan suatu keterampilan berbahasa yang dipergunakan untuk berkomunikasi secara tidak langsung, tidak secara tatap muka dengan orang lain (Tarigan, 1994:3). Ini berarti menulis adalah sebuah kegiatan yang dilakukan untuk menyampaikan ide atau gagasan secara tidak langsung dan dalam bentuk tulisan sehingga pesan yang ingin disampaikan oleh penulis dapat dimengerti dan dipahami oleh pembacanya.

Dalam ragam bahasa tulis inilah, banyak ditemukan kesalahan berbahasa, khususnya yang barkaitan dengan kesalahan tata bahasa. Hal ini karena Bahasa tulis dapat dianalisis berkali-kali sebelum maksud dari tulisan tersebut dapat dipahami oleh pembacanya. Maka dari itu, sebuah tulisan harus dilengkapi 
dengan tanda baca yang tepat agar tidak terjadi kesalahan pengertian oleh pembaca. Kesalahan-kesalahan bahasa tulis biasanya berupa kesalahan sintaksis dan morfologi yakni kesalahan struktur kalimat, pemilihan kata dan pembentukan kata. Kesalahankesalahan ini terjadi bukan hanya pada penulis-penulis pemula seperti pada siswa SD, SMP, dan SMA melainkan juga pada pelajar yang tingkat pendidikannya sudah mencapai perguruan tinggi. Kesalahan tersebut sering terlihat dalam penulisan makalah oleh mahasiswa. Tulisan yang sering dibuat oleh mahasiswa adalah tulisan ilmiah dalam bentuk makalah.

Kesalahan struktur kalimat dan pembentukan kata dapat menyebabkan kesalahan penafsiran pada kalimat yang ditulis. Sehubungan dengan struktur kalimat, kesalahan struktur kalimat dapat menyebabkan sebuah kalimat yang ditulis tidak bersubjek atau tidak berpredikat. Hal ini sering terjadi ketika penulis membuat kalimat yang terlalu panjang. Hal yang penulis perhatikan hanyalah panjangnya kalimat yang dibuat agar dapat dimengerti oleh pembacanya tanpa memikirkan struktur kalimat yang harus ada sehingga kalimat yang dibuat malah menjadi kalimat pragmentaris karena tidak memiliki subjek atau predikat.

Untuk pembentukan kata, banyak yang tidak sadar bahwa hal ini sangat penting. Ketika suatu kata mengalami proses morfologi, terkadang kata tersebut mengalami perubahan kelas kata. Kalimat yang didalamnya menggunakan suatu kata dengan kelas kata yang berbeda meskipun kata dasarnya sama akan memiliki makna dan interpretasi yang berbeda. Hal inilah yang membuat penelitian ini menjadi penting karena pada kenyataannya, masih ada kesalahan struktur kalimat dan kesalahan pembentukan kata pada tulisan ilmiah mahasiswa Program Studi Pendidikan Olahraga dan Kesehatan pada matakuliah Bahasa Indonesia semester II.

Makalah merupakan salah satu contoh sebuah karya ilmiah. Karya ilmiah merupakan karya tulis yang telah diakui di bidang ilmu pengetahuan, teknologi atau seni. Bentukbentuk karya ilmiah antara lain makalah, skripsi, tesis, disertasi, dan lain-lain. Bentuk penulisan karya ilmiah yang sering dibuat oleh mahasiswa adalah makalah. Makalah adalah karya tulis ilmiah yang menyajikan permasalahan serta pembahasannya berdasarkan data dan fakta yang ditemukan di lapangan dan didukung teori-teori atau kepustakaan yang bersifat empiris dan objektif.

Kesalahan-kesalahan yang terlihat dalam penulisan makalah tersebut membuat gagasangagasan atau ide-ide yang ingin disampaikan penulis dalam hal ini mahasiswa tidak dapat tersampaikan dengan baik. Bahkan, bisa saja penggunaan kalimat atau pembentukan kata yang digunakan oleh penulis membuat pemahaman pembaca bertolak belakang dengan gagasan penulis.

Bahasa yang digunakan dalam sebuah karya ilmiah haruslah menggunakan bahasa Indonesia Baku, lugas, jelas, dan objektif. Bahasa Baku adalah Bahasa Indonesia yang sesuai dengan kaidah kebahasaan bahasa Indonesia (Alwi, dkk, 2003:3). Selain itu, bahasa yang mengandung unsur kejelasan adalah bahasa yang mudah dimengerti, tidak berbelit-belit namun tetap mampu menyampaikan ide atau gagasan yang ada dalam pikiran penulis.

Bahasa dalam penulisan sebuah makalah merupakan media utama yang memiliki peranan sangat penting. Namun, dalam hal ini masih banyak ditemukan makalah-makalah yang dibuat oleh mahasiswa Program Studi Pendidikan Olahraga dan Kesehatan pada mata kuliah Bahasa Indonesia semester II yang mengalami kesalahan-kesalahan berbahasa seperti kesalahan struktur kalimat, pemilihan kata, dan pembentukan kata.

Mengingat masih banyak mahasiswa yang melakukan kesalahan berbahasa saat menulis makalah, perlu dikaji lebih lanjut permasalahan-permasalahan berkaitan dengan kesalahan berbahasa khususnya kesalahan gramatika. Untuk itu, peneliti mencoba mendeskripsikan agar kesalahan-kesalahan tersebut dapat berkurang pada pembuatan makalah selanjutnya.

\section{METODE PENELITIAN}

Metode penelitian memiliki peran yang sangat penting dalam sebuah penelitian. 
Penelitian ini dirancang dengan metode yang dapat membantu mengarahkan penelitian yang dilaksanakan. Uraian metode penelitian ini meliputi (1) rancangan penelitian, (2) subjek penelitian dan objek penelitian, (3) populasi dan sampel (4) metode pengumpulan data, dan (5) metode analisis data.

Wendra (2011: 32) menyatakan bahwa rancangan penelitian dapat diartikan sebagai strategi mengatur latar (setting) penelitian agar peneliti memperoleh data yang tepat (valid) sesuai dengan karakteristik variabel dan tujuan penelitian. Penelitian ini menggunakan rancangan penelitian deskriptif kualitatif.

Subjek penelitian ini adalah makalah mahasiswa Program Studi Pendidikan Olahraga dan Kesehatan pada mata kuliah Bahasa Indonesia semester II. Objek yang ingin diteliti dalam penelitian ini adalah kesalahan struktur kalimat serta kesalahan pembentukan kata pada makalah mahasiswa Program Studi Pendidikan Olahraga dan Kesehatan pada mata kuliah Bahasa Indonesia semester II.

Metode pengumpulan data yang digunakan untuk mendukung penelitian ini adalah metode dokumentasi, yaitu peneliti melakukan dokumentasi berupa pencatatan mengenai hal-hal yang terjadi mengenai objek penelitian.

Pada penelitian ini metode analisis data yang peneliti gunakan adalah metode analisis deskriptif kualitatif.

\section{HASIL DAN PEMBAHASAN}

Hasil penelitian ini mencakup dua hal, yaitu (1) kesalahan struktur kalimat dalam makalah mahasiswa dan (2) kesalahan pembentukan kata dalama makalah mahasiswa. Data yang diperoleh berasal dari mahasiswa Program Studi Pendidikan Olahraga dan Kesehatan pada mata kuliah Bahasa Indonesia semester II.

Subjek penelitian yang didapatkan sebanyak 10 makalah mahasiswa Program Studi Pendidikan Olahraga dan Kesehatan pada mata kuliah Bahasa Indonesia semester II. Kesalahan-kesalahan yang didapatkan dibuat dalam bentuk kartu data. Berikut merupakan tabel judul makalah beserta kode nama kelompok yang tercantum dalam kartu data.
Tabel: Judul dan Kode Makalah Mahasiswa Program Studi Pendidikan Olahraga dan Kesehatan pada mata kuliah Bahasa Indonesia semester II

\begin{tabular}{|c|c|c|c|}
\hline No & Judul Makalah & Kode & $\begin{array}{c}\text { Jumlah } \\
\text { Kesalahan }\end{array}$ \\
\hline 1 & $\begin{array}{l}\text { Kedudukan } \quad \text { Bahasa } \\
\text { Indonesia }\end{array}$ & M1 & 2 \\
\hline 2 & $\begin{array}{l}\text { Analisis Percakapan } \\
\text { (Strategi dan Prinsip } \\
\text { Kerja Sama) }\end{array}$ & M2 & 1 \\
\hline 3 & $\begin{array}{l}\text { Fungsi dan Ragam } \\
\text { Bahasa Indonesia }\end{array}$ & & 2 \\
\hline 4 & $\begin{array}{l}\text { Bentuk Tindak Tutur } \\
\text { Berdasarkan Konteks }\end{array}$ & & 2 \\
\hline 5 & $\begin{array}{l}\text { Pemakaian Bahasa } \\
\text { Sarkasme di dalam } \\
\text { Media Sosial }\end{array}$ & & 1 \\
\hline 6 & $\begin{array}{l}\text { Prinsip Kerjasama } \\
\text { Maksim Relevan }\end{array}$ & & 3 \\
\hline 7 & $\begin{array}{l}\text { Diksi dalam Karya } \\
\text { Ilmiah Bahasa } \\
\text { Indonesia }\end{array}$ & & 2 \\
\hline 8 & $\begin{array}{l}\text { Aspek Kognitif } \\
\text { Bahasa }\end{array}$ & & 1 \\
\hline 9 & $\begin{array}{l}\text { Analisis Bentuk } \\
\text { Bahasa Penolakan }\end{array}$ & & 2 \\
\hline 10 & $\begin{array}{l}\text { Klausa Relatif dalam } \\
\text { Bahasa Indonesia }\end{array}$ & & 2 \\
\hline & Jumlah & & 18 \\
\hline
\end{tabular}

Pembahasan tentang tabel hasil di atas diuraikan sebagai berikut.

1) Keutuhan

Kalimat dapat dikatakan efektif jika memiliki ciri keutuhan atau sering juga disebut ciri kesatuan. Betatapapun bentuk sebuah kalimat, baik kalimat inti maupun kalimat luas agar tetap berkedudukan sebagai kalimat efektif, haruslah mengungkapkan sebuah ide pokok atau satu kesatuan pikiran. Dalam suatu kalimat, kesatuan terlihat jika kalimat tersebut meniliki satu gagasan pokok yang jelas. Kalimat yang utuh adalah kalimat yang lengkap, terdiri atas subjek dan predikat. Jika dimungkinkan, sebuah kalimat bisa juga dilengkapi dengan objek dan keterangan. Jika salah satu unsur utama kalimat yakni subjek atau predikat tidak ada, maka kalimat dinyatakan tidak utuh 
atau sering disebut kalimat pragmentaris. Berdasarkan analisis data yang peneliti lakukan, peneliti menemukan beberapa kalimat yang tidak utuh. Salah satu contohnya adalah sebagai berikut.

No : 2

Data : Dan ada lebih banyak fungsi lagi yang dapat dilakukan untuk menginterpretasikan suatu tuturan yang dapat ditemukan dalam ujaran.

Bidang : kesalahan struktur kalimat (kalimat pragmentaris)

Sumber : M2

Perbaikan : Banyak fungsi yang dapat dilakukan untuk menginterpretasikan suatu tuturan dalam sebuah ujaran.

2) Kepaduan

Kepaduan kalimat berhubungan dengan struktur atau interelasi antarunsur dalam kalimat. Dalam sebuah kalimat hubungan antarkata harus jelas dan logis. Kalimat dapat menjadi tidak padu antara lain karena kesalahan penggunaan preposisi, kesalahan penempatan aspek dan kata kerja pendamping serta ketidakparalelan bentuk dan kelas kata. Berdasarkan analisis data yang peneliti lakukan, peneliti menemukan adanya kalimat yang tidak padu dalam makalah diantaranya sebagai berikut

No : 4

Data : Bahasa adalah alat komunikasi verbal yang bersifat arbitrer, bahasa juga merupakan alat penghubung yang berupa symbol tertentu yang telah disepakati sehingga dalam bahasa terjadi interaksi yang saling merespon satu dengan yang lain.

Bidang : kesalahan struktur kalimat (kalimat tidak padu) dan ejaan

Sumber : M4

Perbaikan : Bahasa adalah alat komunikasi verbal dan alat penghubung berupa simbol yang telah disepakati sehingga terjadi interaksi dan saling respon di dalam penggunaannya.

Kalimat pada kartu data nomor 4 di atas dapat digolongkan sebagai kalimat tidak padu karena ketidakjelasan hubungan antarbagian. Dalam kalimat tersebut terjadi pengulangan penyebutan subjek sehingga membuat kalimat tersebut tidak jelas maknanya. Ketidakpaduan suatu kalimat juga bisa disebabkan oleh kontaminasi, yakni penggunaan dua kata yang memiliki makna sama dalam sebuah kalimat.

3) Keringkasan

Keringkasan sering juga disebut kehematan. Kehematan adalah adanya hubungan jumlah kata yang digunakan dengan luasnya jangkauan makna yang diacu. Sebuah kata dikatakan hemat atau ringkas bukan karena jumlah katanya sedikit, sebaliknya dikatakan tidak hemat karena jumlah katanya terlalu banyak (Putrayasa, 2007:55). Dengan kata lain, tidak perlu menggunakan belasan kata, kalau maksud yang dituju dapat dicapai dengan beberapa kata. Setelah melakukan analisis data, peneliti menemukan beberapa kalimat yang tidak memiliki sifat keringkasan di dalamnya.

Berikut contoh kalimat tidak efektif karena tidak memiliki sifat keringkasan.

No : 6

Data : Penelitian yang dilakukan oleh penulis, belum pernah ada yang meneliti tentang Kesantunan Berbahasa dalam Proses Sidang di Pengadilan Negeri Singaraja atau inovasi baru.

Bidang : kesalahan struktur kalimat (kalimat tidak ringkas)

Sumber : M 6

Perbaikan : Penelitian tentang kesantunan berbahasa dalam proses sidang di Pengadilan Negeri Singaraja ini belum pernah dilakukan.

Kalimat di atas digolongkan sebagai kalimat tidak ringkas karena menggunakan lebih dari dua puluh kata, padahal jika beberapa kata dihilangkan, makna kalimat tersebut tidak berubah malah menjadi semakin jelas.

Berdasarkan analisis data yang peneliti lakukan, peneliti menemukan kesalahan kesalahan pembentukan kata sebanyak 6 buah. Kesalahan yang peneliti temukan, kebanyakan merupakan kesalahan pembentukan yang sama antara makalah yang satu dan makalah lainnya. Kesalahan 
pembentukan kata dapat dilihat pada beberapa kartu data berikut.

No : 8

Data : Konteks verbal atau situasi, dapat mempengaruhi makna sebenarnya dari sebuah kata, frase, kalimat, atau ujaran.

Bidang : kesalahan struktur kata (pembentukan kata dan pemilihan kata)

Sumber : M 8

Perbaikan : Konteks verbal atau situasi, dapat memengaruhi makna sebenarnya dari sebuah kata, frase, kalimat, dan ujaran

Kata mempengaruhi pada kartu data nomor 8 merupakan bentukan kata yang salah. Kata-kata yang diawali dengan konsonan [p] jika bertemu dengan awalan meN- harus mengalami peluluhan konsonan. Artinya, konsonan yang mengawali kata tersebut melebur sesuai dengan nasal awalannya. Jadi, kata pengaruh yang diberi imbuhan meNmengalami perubahan bentuk menjadi memengaruhi. Sudiara (2008:29) menyatakan bahwa kata dasar yang konsonan awalnya $[\mathrm{k}],[\mathrm{p}]$, [t], dan [s], jika mendapat awalan me $(\mathrm{N})-$ dan $\operatorname{pe}(\mathrm{N}),[\mathrm{k}]$. [p], [t] dan [s] itu berubah sesuai dengan nasalnya.

\section{KESIMPULAN}

Berdasarkan masalah yang telah peneliti kaji, hasil kajian kesalahan gramatika pada makalah mahasiswa Program Studi Pendidikan Olahraga dan Kesehatan pada mata kuliah Bahasa Indonesia semester II dapat disimpulkan bahwa kesalahan struktur kalimat dalam makalah-makalah yang telah diteliti terjadi akibat kesalahan mahasiswa dalam menata kata dalam sebuah kalimat sehingga kalimat yang tertulis mengalami banyak kesalahan seperti kalimat menjadi ambigu, pleonastis, tidak padu dan tidak ringkas. Selain itu, banyaknya kalimat yang diawali dengan kata sambung membuat kalimat yang idak lengkap strukturnya, baik tidak tampaknya subjek maupun predikat dalam kalimat. Kesalahan pemilihan kata dan dan kesalahan penggunaan tanda baca juga menyebabkan kalimat yang dibuat menjadi tidak jelas maknanya atau rancu (kontaminasi) dan menggandakan makna kalimat tersebut (ambigu). Simpulan lainnya adalah kesalahan pembentukan kata dalam makalah mahasiswa Program Studi Pendidikan Olahraga dan Kesehatan pada mata kuliah Bahasa Indonesia semester II yang dominan adalah kesalahan penulisan bentukan kata yang diawali konsonan $[\mathrm{k}],[\mathrm{p}],[\mathrm{t}],[\mathrm{s}]$ ketika mendapat imbuhan meN-. Kesalahan tersebut terjadi karena entukan kata yang salah lebih lazim digunakan dalam kehidupan sehari-hari.

Berdasarkan hasil analisis data dan simpulan penelitian ini, ada beberapa saran yang peneliti sampaikan adalah kesalahan bahasa tidak pernah lepas dari pembelajaran bahasa itu sendiri. Untuk itu, mahasiswa Program Studi Pendidikan Olahraga dan Kesehatan pada mata kuliah Bahasa Indonesia semester II diharapakan mampu memahami dan mempelajari pembinaan Bahasa Indonesia yang diberikan sehingga kesalahan berbahasa dapat diminimalkan. Penelitian ini juga diharapakan bisa dijadikan bahan atau sumber pengetahuan bagi mahasiswa dalam menggunakan Bahasa Indonesia dalam penulisan makalah selanjutnya. Dari kesalahan pembentukan kata yang peneliti temukan, mahasiswa hendaknya lebih memerhatikan bentukan kata yang terjadi setelah proses morfologi. Hal ini dikarenakan beberapa kata dasar mengalami peluluhan pada huruf pertamanya jika mendapat imbuhan tertentu.

Saran terakhir yaitu mahasiswa diharapakan mampu mengaplikasikan secara benar ilmu tata bahasa yang dimiliki ketika membuat sebuah makalah. Ada baiknya, mahasiswa menggunakan Kamus Besar Bahasa Indonesia dan Pedoman Umum Ejaan Bahasa Indonesia sebagai pedoman ketika membuat sebuah karya ilmiah.

\section{DAFTAR PUSTAKA}

Alwi, Hasan dkk. 2003. Tata Bahasa Baku Indonesia. Jakarta: Balai Pustaka.

Depdiknas. 2008. Kamus Besar Bahasa Indonesia. Jakarta: Gramedia.

Putrayasa, IB. 2008. Kajian Morfologi (Bentuk Derivaksional dan Infraksional). Bandung: Refika Aditama. 2009. Jenis Kalimat dalam Bahasa Indonesia. Bandung: Refika Aditama. 
terakreditasi Peringkat 4 (No. SK: 36/E/KPT/2019)

Sudiara, I Nyoman Seloka. 2008. Modul Pembinaan dan Pengembangan Bahasa Indonesia. Singaraja: Universitas Pendidikan Ganesha.

Sugiyono. 2010. Metode Penelitian Pendidikan, Pendekatan Kualitatif, Kuatitatif, dan $R \& B$. Bandung: Alfabeta.

Tarigan, Henry Guntur. 1994. Menulis sebagai Suatu Keterampilan Berbahasa. Bandung: Angkasa. 1998. Pengajaran Analisis Kesalahan. Bandung: Angkasa

Wendra, I Wayan. 2011. Buku Ajar Penulisan Karya Ilmiah. Singaraja: Undiksha. 